\title{
PKM TTG KOPI BUBUK UNTUK MENINGKATKAN KAPASITAS DI BENOWO SURABAYA
}

\author{
Imam Kholiq ${ }^{1}$, Yeni Probowati ${ }^{2}$ \\ ${ }^{1}$ Universitas Wijaya Putra,Fakultas Teknik ,Program Studi Teknik Mesin \\ ${ }^{2}$ Universitas Wijaya Putra,Fakultas Sastra ,Program Studi Bahasa Inggris \\ e-mail ${ }^{1}$ : $\underline{\text { imamkholik@uwp.ac.id }}$ \\ e-mail 2: yeniprobowati@uwp.ac.id
}

\begin{abstract}
ABSTRAK
Di Negara Indonesia produksi biji kopi secara signifikan terus meningkat, namun mutu hasil pengolahan kopi yang dihasilkan umumnya masih rendah. Salah satu kendala pengembangan industri kopi adalah tidak tersedianya mesin sangrai yang murah, efisien dan mampu menghasilkan produk yang kompetitif. Produsen kopi merupakan investasi usaha yang cukup bagus karena proses produksi yang relatif cepat, mudah dan dalam proses produksinya menggunakan peralatan yang sederhana. Pengusaha produsen kopi masih menggunakan system manual, menyangrai dengan menggunakan alat sederhana, sehingga kapasistas produksinya relative sangat rendah. Guna mengatasi permasalahan tersebut dari Tim Program Kemitraan Masyarakat ( PKM) Fakultas Teknik Universitas Wijaya Putra merancang dengan membuat dan menerapkan mesin Teknologi Tepat Guna (TTG) sebuah mesin sangrai tipe silinder horizontal dengan hasil produksinya lebih banyak. Hal ini berdampak pada peningkatan Kapasitas \& efisiensi produktivitas pada mitra pengusaha produsen kopi bubuk di Pasar Benowo Surabaya Barat. Hasil yang didapat dari kegiatan ini: 1) mesin sangrai tipe silinder horizontal dapat mempercepat proses penyangrai kopi bubuk dengan kualitas baik. 2) keberadaan mesin sangrai tipe silinder horizontal ini dapat meningkatkan produktivitas mitra menjadi 10 kali, yang sebelumnya hanya $4 \mathrm{~kg} / \mathrm{jam}$ menjadi $40 \mathrm{~kg} / \mathrm{jam}, 3$ ) Output yang dihasilkan lebih berkualitas dan lebih sempurna, 4) meringankan beban tenaga kerja karena tenaga manusia tergantikan oleh mesin.
\end{abstract}

Katakunci: TTG,UKM,Kopi,Produktivitas,Effisiensi. 


\section{PENDAHULUAN}

\subsection{Analisis Situasi}

Usaha produsen Kopi Bubuk yang beralamatkan di Pasar Benowo Surabaya.

Usaha produsen Kopi Bubuk ini sudah berdiri sejak tahun 2007, tenaga yang memproduksi ini sistem keluarga jumlah anggota sebanyak 5 orang semuanya. 2 orang yaitu bagian pengolah,3 orang tenaga penjualan. Sistem administrasi keuangannya belum teratur dan tidak mempunyai pembukuan. Produsen Kopi

Bubuk di Pasar Benowo Surabaya ini sangat terkenal selain enak cita rasa kopinya.

Pengusaha Produsen Kopi Bubuk sebagai mitra usulan PKM terdiri dari 2 (dua) mitra dalam satu wilayah:

1. Pengusaha Produsen Kopi Bubuk "S Ghozali Maksum" yang beralamatkan di Pasar Benowo Surabaya ,berdiri sejak tahun 2007.

2. Pengusaha Produsen Kopi Bubuk "Abdul Ghofur" yang beralamatkan di Pasar Menganti Gresik, berdiri sejak tahun 2009.

Menurut hasil wawancara dari kedua pengusaha Produsen Kopi Bubuk kondisi saat ini .
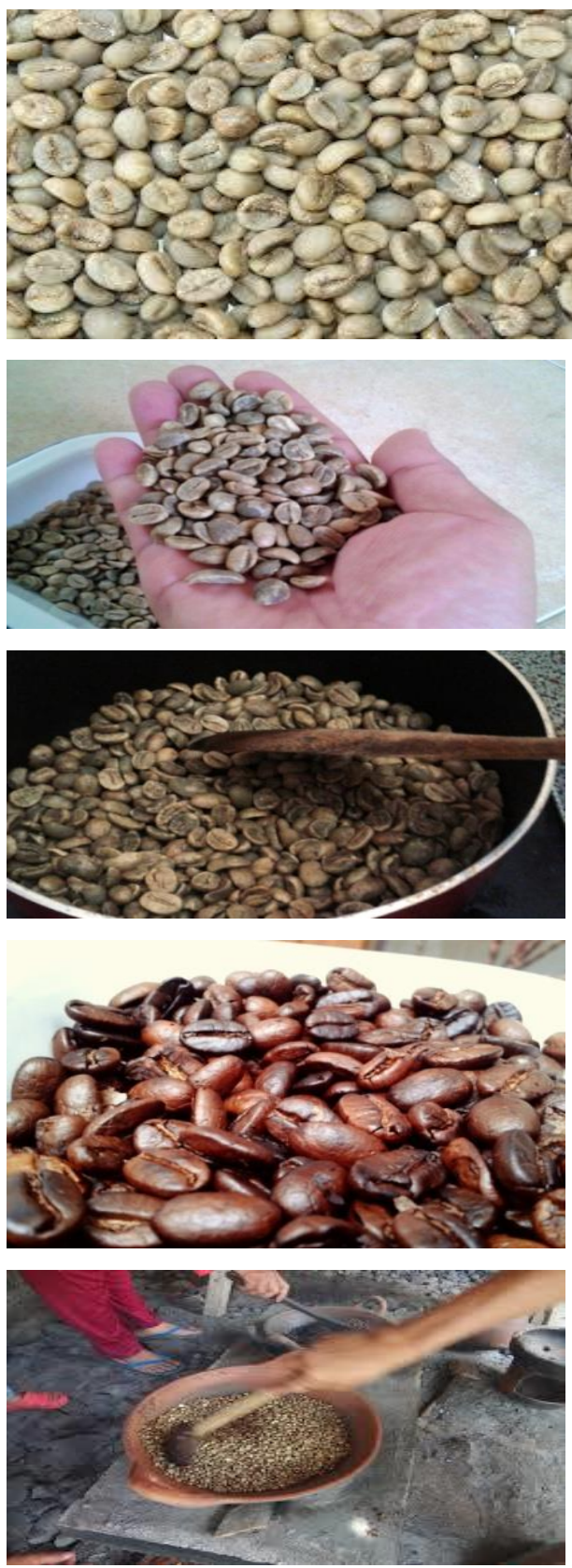

Gambar 1 kopi diproduksi dengan sederhana.

Mitra dalam Abdimas dan apabila dihitung berdasarkan jarak tempuh antara kedua mitra dengan UniversitasWijaya Putra Surabaya sekitar $6 \mathrm{~km}-7 \mathrm{~km}$ atau waktu tempuh sekitar 30 menit - 40 menit (mitra Teknologi Tepat Guna 341 
ke 1 dengan Universitas Wijaya Putra Surabaya berjarak $13 \mathrm{~km}$ dan mitra ke2 dengan Universitas Wijaya Putra Surabaya berjarak $15 \mathrm{~km}$ ). Kedua jenis usaha tersebut berdiri sejak tahun 2009-an.

\subsection{Permasalahan Spesifik Mitra}

Berdasarkan kondisi riil sebagaimana yang dijelaskan dalam analisis situasi, maka permasalahan yang dihadapi mitra dapat dibagi menjadi dua yaitu :

\section{Permasalahan produksi.}

Ketidakmampuan mitra meningkatkan kapasitas produksi sesuai dengan permintaan pasar yang terus meningkat sehingga proses produksi yang saat ini menggunakan cara manual tidak efisien.

2. Manajemen usaha.

Manajemen usaha diklasifikasikan menjadi permasalahan pemasaran, kewirausahaan, administrasi keuangan serta manajemen mutu dan kesehatan.

\section{TARGET LUARAN}

Target luaran yang diharapkan atau yang ingin dicapai dari kegiatan ini adalah :

1. Kedua mitra diharapkan memiliki modal mesin untuk produksi serta manajemen usaha yang baik.

2. Kedua mitra diharapkan mampu berkembang menjadi wirausaha yang siap memenuhi permintaan konsumen serta siap dalam persaingan iklim kompetisi usaha.

3. Selain luaran penerapan teknologi tepat guna (TTG) dan manajemen usaha yang baik bagi mitra untuk memproduksi kopi target luaran dari kegiatan ini adalah publikasi dalam jurnal nasional.

\section{METODE PELAKSANAAN}

Metode pelaksanaan kegiatan PKM bagi usaha kopi bubuk di Desa Benowo Surabaya dan Desa Mengganti Gresik melalui teknik pendampingan, pelatihan manajemen usaha (manajemen mutu dan kesehatan), alat potong kerupuk inovatif, pelatihan administrasi dan pelatihan pembuatan produk bercita rasa.

Metode pelaksanaannya sebagai berikut :

1. Pendampingan.

Kegiatan ini dilakukan dalam bentuk pendampingan langsung kepada pemilik usaha kopi bubuk. Mahasiswa yang terlibat sebanyak dua orang yang mana dibagi atas dua pemilik usaha kopi bubuk sehingga satu pemilik usaha didampingi oleh satu mahasiswa sebagai pendamping dan dua dosen pelaksana kegiatan pengabdian PKM. Teknik pelaksanaan dengan model kunjungan semingggu sekali ke mitra selama delapan bulan serta dosen pelaksana 
tetap melakukan kegiatan pendampingan dan monitoring hingga kegiatan PKM berakhir. Kegiatan pendampingan yang dilakukan meliputi kegiatan observasi, brainstorming dan diskusi, upaya perbaikan produk (kemasan, inovasi), pengoperasian alat Sangrai kopi yang inovatif dan hiegienis, perbaikan administrasi keuangan, pemilihan pasar potensial serta cara pemasaran produk, penerapan manajemen mutu dan kesehatan produk yang hiegienis serta pengurusan sertifikat.

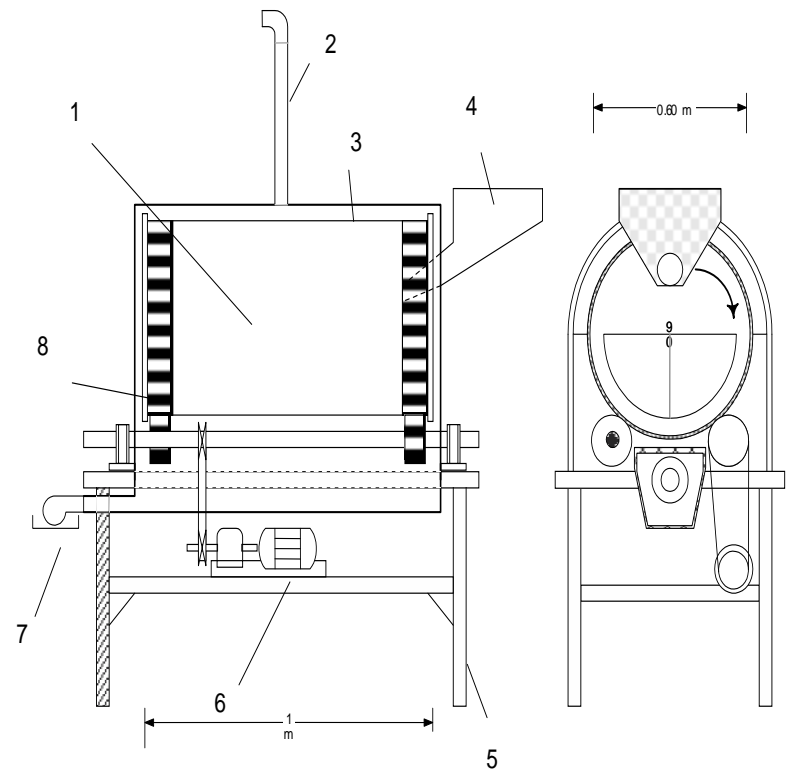

Gambar 2 Desain Mesin Sangrai Silinder Horisontal ( Tehnologi Tepat Guna )

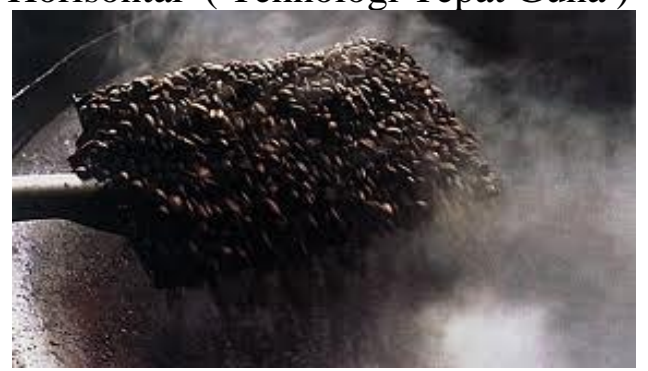

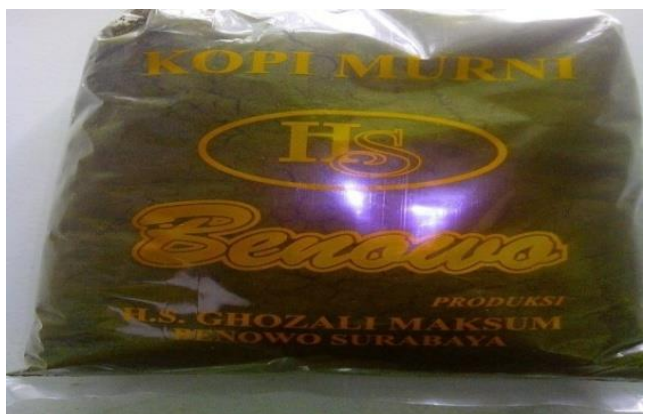

Gambar 3 Pengolahaan Kopi dengan Mesin Sangrai Silinder Horisontal(TTG ).

\section{Pelatihan Manajemen.}

Kegiatan PKM dari sisi manajemen adalah bagaimana upaya-upaya untuk mempromosikan usaha, sistem pengelolaan manajemen. Upaya yang dilakukan untuk melakukan promosi adalah dengan membuat label / merk serta kemasan yang menarik di tiap-tiap pemilik usaha kopi bubuk. Cara tersebut diharapkan masyarakat mengetahui usaha kopi bubuk ini sehingga efek promosi dapat dirasakan oleh pemilik usaha kopi bubuk tersebut. Selain itu upaya promosi untuk memperkenalkan pemilik usaha kopi bubuk serta secara menyeluruh daerah Kecamatan Benowo Surabaya dan Kecamatan Menganti sebagai sentra kopi bubuk, dilakukan dengan pembuatan papan petunjuk sentra kopi.

3. Pembuatan mesin sangrai inovatif untuk meningkatkan produktivitas kopi bubuk yang enak, cepat dan higienis. 
b. Pelatihan dan pendampingan pengoperasian alat mesin sangrai.

c. Evaluasi hasil pemakaian peralatan mesin sangrai tehnologi tepat guna, cepat dan hiegienis

4. Pelatihan Administrasi Keuangan.

Pelatihan administrasi keuangan lebih banyak ditekankan pada upaya perbaikan pembukuan. Ini dilakukan karena semua pemilik usaha kopi bubuk ini belum memiliki sistem pembukuan, semua masih dilakukan secara campur aduk. Pelatihan dilakukan pada pembuatan catatan pembukuan keuangan sederhana. Ini dilakukan supaya pemilik usaha dapat memisahkan antara keuangan usaha dengan keuangan keluarga, dapat menghitung harga pokok produksi dan akhirnya dapat menghitung laba / rugi usaha.

5. Pelatihan Manajemen Mutu dan

Kesehatan.

Pelatihan manajemen mutu dan kesehatan diupayakan untuk semakin mengenalkan pemilik usaha kopi bubuk tentang cara memproduksi kopi yang sehat dan hiegienis. Pelatihan ini ditujukan kepada pemilik usaha kopi untuk mengetahui proses produksi yang tepat, penggunaan peralatan yang hiegienis serta mendapatkan sertifikasi label halal.

4.HASIL PELAKSANAAN KEGIATAN

\section{Hal-hal yang telah dilakukan.}

a. Persiapan.

1. Melakukan koordinasi dengan memetakan seluruh kegiatan pengabdian, serta memperjelas job description ketua, anggota dan mahasiswa pelaksana dalam kegiatan pengabdian.

2. Pembahasan dan pembuatan materi.

3. Penentuan jadual kegiatan pelatihan dan workshop pembuatan produk.

4. Turun ke sentra.

5. Tim pengabdian ini telah melakukan kegiatan pelatihan dan workshop pembuatan produk di masingmasing sentra sebanyak 3 kali. Selama 3 kali pelatihan dan workshop, tahap-tahap penting terkait proses pembuatan kopi bubuk sebagai teknik finishing produksi kopi bubuk di Desa Benowo dan Menganti. Kegiatan pelatihan ini, membagi peserta menjadi 2 kelompok dengan Bapak Ghozali Maksum dan Abdul Ghofur sebagai ketua. Setiap kelompok terdiri dari 2 orang karyawan yang sehari-harinya mereka mengerjakan dan membuat kopi bubuk.

b. Tahap proses pelaksanaan pengabdian secara umum terbagi sebagai berikut :

1. Pengarahan atau sosialisasi.

2. Pelatihan sistem pengelolaan Teknologi Tepat Guna 344 
manajemen.

3. Pelatihan pengoperasian alat Mesin

Sangrai kopi.

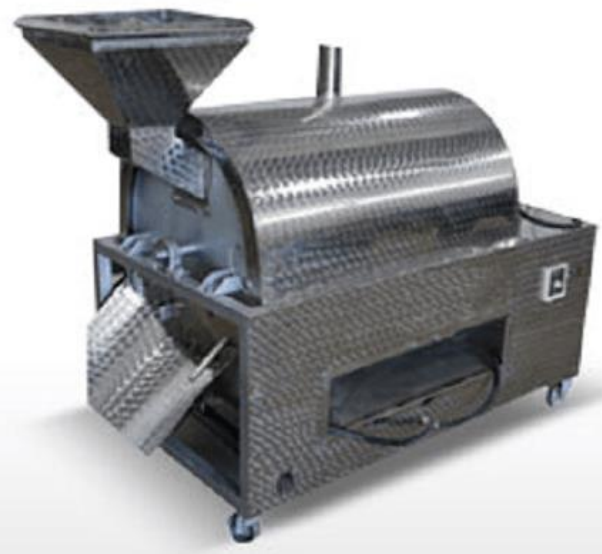

Gambar 3 Mesin Sangrai Silindir

Horisontal TTG

4. Pelatihan administrasi keuangan.

5. Pelatihan manajemen mutu dan kesehatan.

\section{Hal-hal yang sudah dilakukan.}

a. Pembuatan alat pensangrai (TTG).

b. Dokumentasi kegiatan.

c. Evaluasi.

\section{Faktor-faktor.}

1. Faktor-faktor yang mendukung kegiatan pengabdian kepada masyarakat :

a. Respon positif dari Universitas

Wijaya Putra Surabaya.

b. Respon positif dari masyarakat industri kopi di Benowo dan Mengganti .

c. Lokasi mudah dijangkau. d. Keterlibatan mahasiswa yang mampu mendukung jalannya kegiatan dengan cara mencatat hasil kegiatan dan evaluasi, membantu pemilik usaha dalam mengoperasikan alat serta pemeliharaan alat, membimbing pemilik usaha dalam proses workshop, dan mendokumentasikan jalannya kegiatan dengan baik.

2. Faktor-faktor yang menghambat.

Secara umum faktor-faktor yang menjadi hambatan dalam pengabdian kepada masyarakat belum kami jumpai. Namun keterlambatan pencairan dana menjadi hambatan dalam kegiatan ini. Keterlambatan tersebut berpengaruh terhadap proses pembuatan alat TTG mesin Sangrai yang memerlukan biaya alat bahan yang tidak sedikit. Selain itu, waktu yang diperlukan juga lama agar dapat diperoleh hasil maksimal.

Semua hambatan tersebut bisa diatasi dengan cara mengatur ulang jadual kegiatan sehingga semua dapat berjalan dengan baik.

3. Dokumentasi Kegiatan.

4. Uraian Kegiatan.

Kegiatan pelatihan manajemen akuntansi bagi UMKM untuk meningkatkan kinerja usaha dilakukan selama tiga tahap dalam setiap tahap dilaksanakan dua minggu sekali.

\section{KESIMPULAN DAN SARAN}

\subsection{Kesimpulan}

Kami percaya bahwa kegiatan ini dapat mengembangkan dan mengarahkan Teknologi Tepat Guna 345 
kegiatan produksi kopi bubuk di Desa Benowo dan Mengganti ke arah yang lebih prospektif, sehingga produksi kopi bubuk yang diciptakan memiliki nilai tawar lebih. Merangsang produksi kopi melalui pelatihan dalam bentuk pendampingan, pada sisi lain memiliki peran yang aktif produksi kopi bubuk dalam pengembangan keterampilan dalam penciptaan produksi kopi yang lebih kreatif.

\subsection{Saran}

Kegiatan pengabdian kepada masyarakat di bidang produksi kopi sebagai salah satu ikon penguat di Mengganti dan Benowo diharapkan dapat berkesinambungan dalam upaya pembangunan mentalitas wirausaha masyarakat. Selain itu, bagi produksi kopi bubuk yang sudah produktif dalam berkreasi dapat meningkatkan kualitas produk dan sistem promosi yang benar, efektif dan efisien.

\section{UCAPAN TERIMAKASIH}

Ucapan terimakasih kepada Universitas Wijaya Putra Surabaya.yang telah memberikan kontribusi dalam pelaksanaan kegiatan.

\section{DAFTAR PUSTAKA}

Ahmadi, Fuad, (2011). Karakteristik Teknologi Tepat Guna dalam Industri Skala Usaha Kecil dan Menengah di Jawa Timuri. Surabaya: Makalah yangdisampaikan dalam rangka pelatihan produktivitas usaha kecil di Unesa.Tanggal 26 Juli tahun 2011.

Biegel JE, (2010). Pengendalian Produksi, Suatu Pendekatan Kuantitatif, Terjemahan, Bandung: Tarsito.

Kotler, Philip, (2009). Marketing Management. Engelwood Cliffs: Prentice Hall

International Inc. A Division of Simoon and Scuster.

Nyoman, Sutantra I, (2011). Produktivitas Sistem Produksi dan Teknologi. Surabaya: Makalah yang disampaikan dalam rangka pelatihan produktivitas usaha kecil di Unesa. Tanggal 26 Juli tahun 2011

Soegoto, Eddy Soeryanto, (2019). Enterpreneurship Menjadi Pebisnis Ulung. Jakarta: PT Elex Media Komputindo. Subanar, (2012). Permasalahan Usaha Kecil Menengah. Surabaya: Dinas/Kanwil Perindustrian Jawa Timur. 